\title{
Analysis of skull morphometric characters in diurnal raptors (Accipitriformes and Falconiformes)
}

\author{
Tibor PeCsics ${ }^{1 *}$, Miklós LaCZi ${ }^{1,3}$, Gergely NAGY ${ }^{1}$, Tamás Kondor ${ }^{1}$ \\ \& Tibor CsÖRGÖ2
}

Received: March 28, 2018 -Revised: April 16, 2019 -Accepted: April 26, 2019

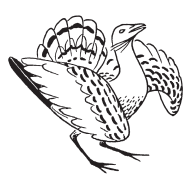

Pecsics, T., Laczi, M., Nagy, G., Kondor, T. \& Csörgö, T. 2018. Analysis of skull morphometric characters in diurnal raptors (Accipitriformes and Falconiformes). - Ornis Hungarica 27(1): 117-131. DOI: 10.2478/orhu-2019-0008

Abstract Diurnal birds of prey (Accipitriformes and Falconiformes) has traditionally been known as comprising a single order. Recently, this classification has been used in the non-taxonomic sense as referring to a convergent group of birds that are largely classified as predatory birds. Although these birds are similar in their morphology, the species differ in their foraging methods and prey preference. The cranial shape and the physical attributes determine the efficiency of the resource use. The aim of this study is to increase our knowledge of the relationship between skull shape, prey preference, and foraging habits. A geometric morphometric approach was used to analyse two-dimensional cranial landmarks. We used principal component (PC) analyses on measurements that may be related to prey preference and foraging habits. The PCs are resulted described the relative height of the skull and beak, the variation in the relative size, the orientation and robustness of the lacrimal bone, the variation in the relative size of the neurocranium compared to the viscerocranium, and the orientation of the palatine bone. The dietary categories significantly overlap. The skull morphology reflects more on foraging habits than diet or prey preference.

Keywords: cranial morphology, morphometric, anatomy, jaw, skull, shape, convergent evolution, diurnal predator, prey preference

Összefoglalás A nappali ragadozó madarakat (Accipitriformes és Falconiformes) ma is szokás egy csoportként kezelni, bár nem rendszertani értelemben. Külső jegyeiket és megjelenésüket tekintve nagyon hasonlóak, ám a fajok eltérnek a táplálkozás-mechanizmust és a prédaállatokat illetően. Mindezek a koponyán is megfigyelhető adaptációt mutatnak. Tanulmányunkban e madarak cranialis jegyeinek elemzésével a táplálékpreferencia, a táplálkozásmód és a morfológiai jellemzök közötti lehetséges összefüggéseket kerestük. A vizsgálat során kétdimenziós landmarkok használatával fökomponens-analíziseket végeztünk. A fökomponensek a koponya és a csőr relatív magasságát, a könnycsont nagyságát, helyzetét és robuszticitását, az agy- és arckoponya egymáshoz viszonyított nagyságát, valamint a palatinum relatív nagyságát és helyzetét magyarázzák. Az egyes táplálkozási csoportok nagymértékben átfednek egymással. A koponyamorfológia sokkal inkább tükrözi a táplálékszerzés módját, mint a táplálékpreferenciát.

Kulcsszavak: koponya-sajátosságok, morfometria, anatómia, állkapocs, koponya, alak, konvergens evolúció, nappali ragadozó, táplálékpreferencia

${ }^{1}$ Behavioural Ecology Group, Department of Systematic Zoology and Ecology, Eötvös Loránd University, 1117 Budapest, Pázmány Péter sétány 1/C, Hungary

${ }^{2}$ Department of Anatomy, Cell- and Developmental Biology, Eötvös Loránd University, 1117 Budapest, Pázmány

Péter sétány $1 / C$, Hungary

${ }^{3}$ The Barn Owl Foundation, 8744 Orosztony, Temesvári út 8., Hungary

* corresponding author: nobilis.equus@gmail.com 


\section{Introduction}

Birds of prey are small to large raptors which hunt and feed on other animals. Many species of these birds are apex predators in the food chain. There are insectivores, piscivores, avivores, mammalivores, scavengers, and we can find both generalist and highly specialized species (Bijleveld 1974, Cramp 1980).

Traditionally, this group includes the diurnal and the nocturnal predators. The diurnal birds of prey are formally classified into five families of three orders: Accipitridae (hawks, eagles, buzzards, harriers, kites and Old World vultures), Pandionidae (Osprey - Pandion haliaetus), Sagittariidae (Secretary Bird - Sagittarius serpentarius), Falconidae (falcons, caracaras and forest falcons) and Cathartidae (New World vultures) (Yuri et al. 2013, Jarvis et al. 2014).

Diurnal birds of prey have traditionally been treated as comprising a single order. However, as relationships between different higher taxa are uncertain and the whole assemblage is polyphyletic, that is why the phrase "diurnal bird of prey" should be used in non-taxonomic sense as referring to a convergent group of predatory birds (Helbig et al. 1994). Recent analyses show that the traditional raptor families Accipitridae (hawks, eagles, kites, Old World vultures) and Falconidae (falcons, caracaras) are not sister taxa (Barker et al. 2004, Cracraft et al. 2004, Hackett et al. 2008, McCormack et al. 2013, Jarvis et al. 2014, Prum et al. 2015). Currently, Accipitriformes is the order including hawks, eagles, and kites (Nagy \& Tökölyi 2014), and Falconiformes are reserved for the falcons, falconets, forest falcons, and caracaras (Mindell et al. 2018).

Although the number of morphological similarities is great, ultimately the groups differ in their foraging methods. The foraging performance and the cranial morphology are functionally linked in a number of vertebrate taxa (Anderson et al. 2008). The cranial shape and the physical attributes determine the efficiency of the resource use (Dumont 2003). The feeding methods provide an example of the link between morphological modification and performance (Benkman 2003). Numerous vertebrate taxa show that cranial dimensions are related to the amount of bite force (Csermely et al. 1998, Ward et al. 2002, McBrayer 2004, Van der Meij \& Bout 2004, Anderson et al. 2008, Sustaita \& Hertel 2010). The feeding system of most vertebrates produces bite force by the musculoskeletal system of the head (Herrel et al. 2005).

The feeding strategies are highly diverse and the morphological adaptations for feeding are a notable feature of avian evolution (Zweers et al. 1994). The oral apparatus is comprised of musculoskeletal and neural systems. The avian skull shows a great variety of morphological variation (Zusi 1993). Larger animals generally have access to larger prey due to their greater muscular power and size. These factors are further related to allometry. Allometry has a key role in craniofacial form across a range of bird clades (MarugánLobón \& Buscalioni 2006, Kulemeyer et al. 2009, Fabbri et al. 2017).

There are numerous physical similarities in the prey preference of some groups (e.g. hawks and falcons) but there are notable differences in hunting strategies (Cade \& Digby 1982). For example, accipiters are known for using their legs and talons. The grip force has a clear implication and connectedness to the ability to subdue and kill prey (Csermely 
et al. 1998, Csermely \& Gaibani 1998). Different characteristics of the talons are also seen to have important roles. The morphology and talon size are related to grasp and killing the prey (Csermely \& Rossi 2006, Fowler et al. 2009). Compared to the accipiters, falcons subdue their prey with their feet, but ultimately kill the prey with their beaks. Their jaws deliver powerful bites to the prey's neck and kill the prey by breaking the cervical bones, producing damage to the nerves and spinal cord (Hertel 1995, Csermely et al. 1998, Sustaita \& Hertel 2010).

The bird-eaters have wide skulls and beaks, while the scavenger birds have narrow beaks with greater curvature (Hertel 1995, Ladyguin 2000, Jones et al. 2007, Sustaita \& Hertel 2010).

In most avian lineages, male to male competition for females has led to an increase in male size due to sexual selection; therefore the males are larger than females (Andersson 1994, Colwell 2000). However, in some groups like raptors and owls reversed size dimorphism exists and females are the larger sex (Mueller 1990, Owens \& Hartley 1998) with the exception of the New World vultures (Graves 2017). Reversed sexual dimorphism (RSD) increases with prey size, consistent with the small-male hypothesis (Andersson \& Norberg 1981, Møller \& Garamszegi 2012). The intrasexual dimorphism is visible in the case of numerous vertebrate taxa. In kestrels, the directional selection on a particular size may be under contrasting pressures by the environment, and in breeding females, the advantages of large size can be counterbalanced during harsh environmental conditions (Massemin et al. 2000). However, morphological differences in shape between males and females are undetectable (Verwaijen et al. 2002).

The morphology of the skull, the maxillary and mandibular characteristics and the important details of the skull structure are determinants of the different foraging groups. These two dimensional methods allow size and shape to be considered independently, preserve geometric information, and offer techniques for studying in form (Adams et al. 2004). A previous study in a 2-D geometric morphometric work explored the relationship among skull shape and ecology in scavenging raptors, which reflected the size and structure of the jaw muscles but did not provide further information on other trophic guilds ( $\mathrm{Si}$ et al. 2015).

In this study, we investigated the cranial and morphological diversity among the different groups. Our objective was to increase our knowledge on the relationship between skull shape and foraging habits of diurnal raptors, to find those characters that are related to diet and prey preference, and to find the possible convergent attributes. The differences in force acting on the beak during feeding may be related to skull geometry and jaw musculature. If there is a significant overlap in skull geometry between the species, it would suggest that skull geometry has evolved along similar pathways and has the same mechanical demands. The differences between the species may reflect selection pressures related to the different foraging habits. To investigate the morphological diversity of the skulls between the species, we used landmark-based morphometric methods. 


\section{Materials and methods}

\section{Specimens}

This study is based on 142 skulls of 81 species. All skulls are from adult specimens of raptors and belong to the collection of Eötvös Loránd University (Budapest, Hungary), the collection of the Hungarian Natural History Museum (Budapest, Hungary), and the digital archives of Wageningen University (Wageningen, Netherlands) and Canterbury Museum (Christchurch, New Zealand). No bird has been killed to get its skull; all birds died either of natural causes, accidental death or died in captivity.

\section{Groups and diet}

Before the analyses, we created seven groups, which represent the following diet categories (Hertel 1995, Guangdi et al. 2015). This study seeks to test that the different prey preference may have an effect on skull morphology.

- A: Avivores (Newton 1978, Lindberg \& Odsjö 1983, Hinsley et al. 1995, Dixon et al. 2018)

- B: Mammalivores (Korpimäki 1985, Puzović 2008, Pomichal et al. 2014, Kotymán et al. 2015)

- C: Generalists (Bielefeldt et al. 1992, Graham et al. 1995, Tóth 2014)

- D: Herpetivores (Bakaloudis et al. 1998)

- E: Piscivores (Gende et al. 1997, Sulkava et. al 1997)

- F: Scavengers (Brown \& Plug 1990, Moreno-Opo et al. 2010)

- G: Insectivores (Itämies \& Mikkola 1972, Palatitz et al. 2015, Szövényi 2015).

\section{Landmarks and procedures}

The variation of cranial morphology is analysed using landmark-based geometric morphometry. In our former study, we used conventional morphometric variables which were selected a priori (Pecsics et al. 2017), however in this case the meaningful variables are discovered by the analysis presented in a more recent study (Pecsics et al. 2018). We should not choose them before the analysis. We tried to find landmarks for this analysis to cover the geometric form of the skull. The landmarks provide a comprehensive sampling of morphology and the features of biological significance can be explored. The ideal landmarks are discrete and noticeable anatomical features, do not alter their topological positions relative to other landmarks, and provide adequate coverage of the morphology (Zelditch et al. 2004). The landmarks were taken from high resolution $(1200 \times 1600$ pixels $)$ photos. We took 3 photographs from each specimen (lateral, ventral, and dorsal) with closed jaws and without lower jaw. Images were standardised for the foramen magnum occipitale and the tip of the beak. We investigated the repeatability of the measurements by Spearman's correlation. The test was between two separate digital measures performed on skull photos $(n=20)$. For each specimen, 12 fixed landmarks (Table 1) were recorded in ventral view 
Table 1. Number and description of landmarks. Terminology according to (Baumel 1993, Sun et al. 2018)

1. táblázat Az egyes landmarkok száma és leírása. Terminológia Baumel (1993) és Sun et al. (2018) alapján

\begin{tabular}{|c|l|}
\hline $\begin{array}{c}\text { Number of } \\
\text { landmark }\end{array}$ & \multicolumn{1}{|c|}{ Description of landmark } \\
\hline 1 & tip of the maxilla \\
\hline 2 & $\begin{array}{l}\text { the lateral associating point of } \\
\text { palatine and maxilla }\end{array}$ \\
\hline 3 & $\begin{array}{l}\text { the most anterior-lateral point } \\
\text { of pars lateralis }\end{array}$ \\
\hline 4 & $\begin{array}{l}\text { the most posterior-lateral point } \\
\text { of pars lateralis }\end{array}$ \\
\hline 5 & $\begin{array}{l}\text { processus pterygoideus of } \\
\text { palatine }\end{array}$ \\
\hline 6 & $\begin{array}{l}\text { articulation point of palatine } \\
\text { and maxilla }\end{array}$ \\
\hline 7 & $\begin{array}{l}\text { articulation point pf pterygoid } \\
\text { and quadrate }\end{array}$ \\
\hline 8 & $\begin{array}{l}\text { articulation of quadrate and } \\
\text { jugal }\end{array}$ \\
\hline 9 & most lateral point of opisthotic \\
\hline 10 & prominentia cerebellaris \\
\hline 11 & $\begin{array}{l}\text { most caudal point of foramen } \\
\text { magnum }\end{array}$ \\
\hline 12 & $\begin{array}{l}\text { most caudal point of condylus } \\
\text { occipitalis }\end{array}$ \\
\hline
\end{tabular}

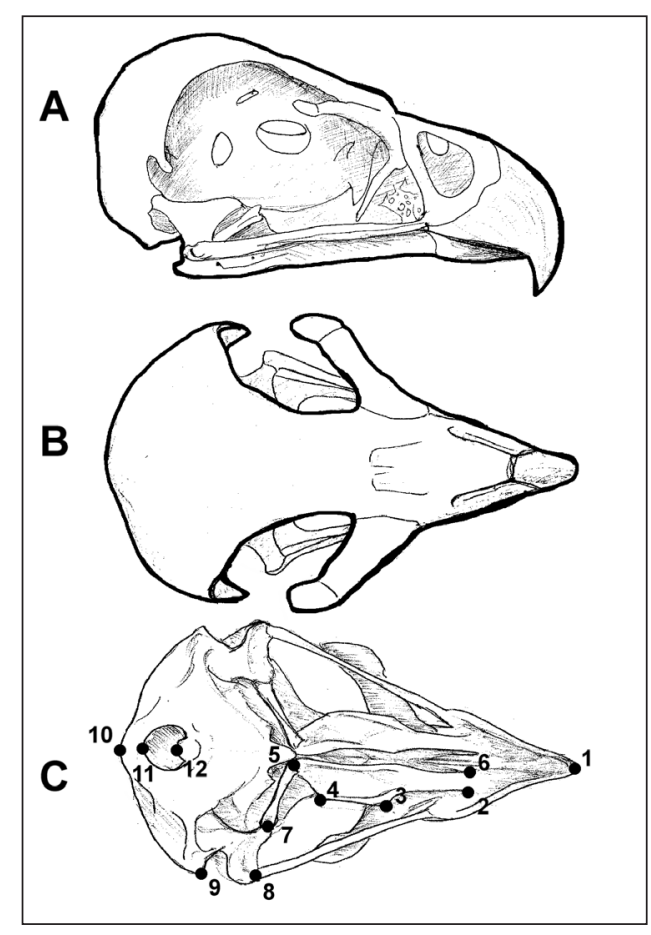

Figure 1. Position and number of landmarks. A: whole skull shape in lateral view, B: whole skull shape in dorsal view, C: the shape fixed landmarks in ventral view (numbers correspond to Table 1)

1.ábra A vizsgálatban használt landmarkok száma és pozíciója. A: a teljes koponya oldalnézetből, B: a teljes koponya felülnézetből, C: fix landmarkok alulnézetből (a számok megnevezését lásd az 1. táblázatban)

(Guangdi et al. 2015, Sun et al. 2018). We used 800 sliding landmarks to examine the shape of the whole skull in dorsal and lateral view (Figure 1). These landmarks were allowed to slide along their corresponding curve due to the minimalization of the bending energy. The coordinates of the landmarks were digitised using TpsDig 2.16 software (Rohlf 2010) and were transformed using the Procrustes superimposition method. Consensus configurations and relative warps were conducted. Variability in shape was assessed using the scores obtained for each individual on the first two relative warps. We conducted principal component analyses (PCA) on these morphological variables. The relative warps correspond to the principal components (PCs) and define the shape space in which individuals are replaced. We used PAST v.1.7 software (Hammer et al. 2001) to perform principal component analysis and extract deformation grids. We only considered those PCs which explain $>10 \%$ of the variance. 


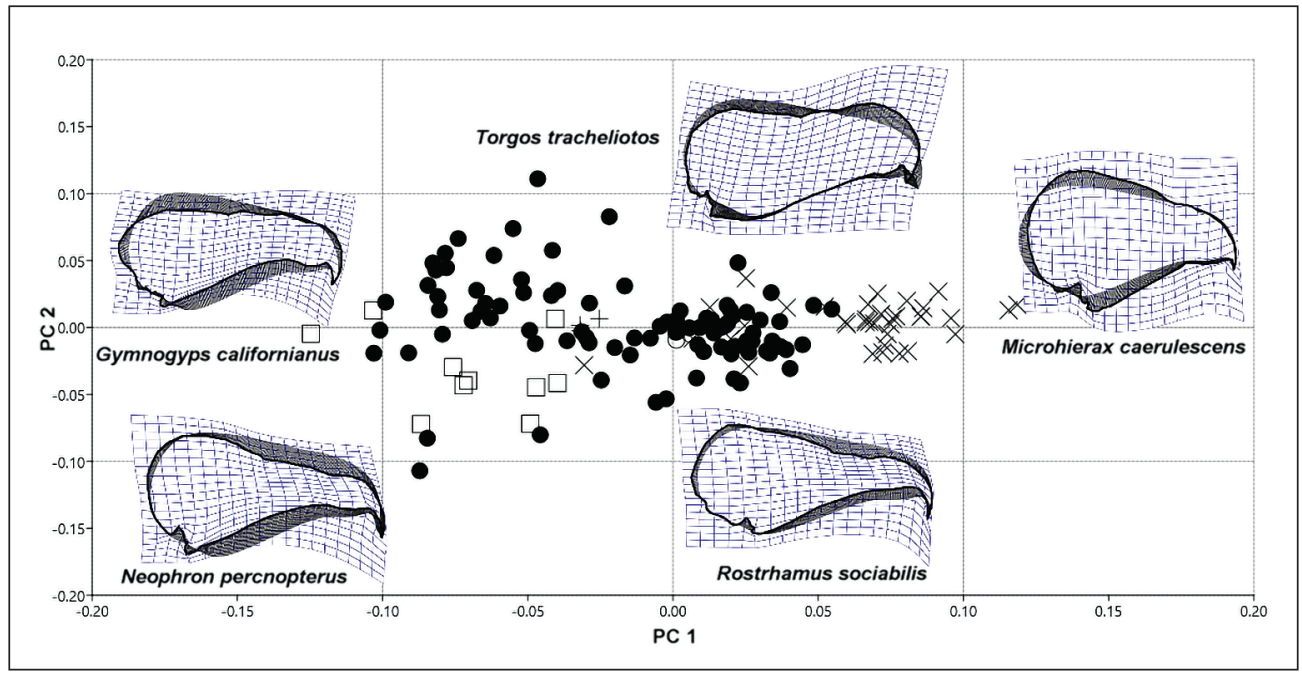

Figure 2. Graphical output of PCA performed on the two-dimensional landmark data (lateral view). PC1-PC2 biplot. The first PC axis described the relative height of the skull (PC1). The second PC axis described the relative highness of the beak (PC2). Thick black areas show the differences compared to the computer generated mean shape

- Accipitridae, $\times$ Falconidae, $\square$ Cathartidae, O Pandionidae, + Sagittaridae

2. ábra A PCA grafikus megjelenítése kétdimenziós landmark adatok alapján (oldalnézet). Az első főtengely a koponya relatív magasságát magyarázza (PC1). A másodikfőtengely a csőr relatív magasságával hozható kapcsolatba (PC2). A fekete, vastagított terület a komputergenerált átlagformától való eltérést mutatja

- Accipitridae, $\times$ Falconidae, $\square$ Cathartidae, $\bigcirc$ Pandionidae, + Sagittaridae

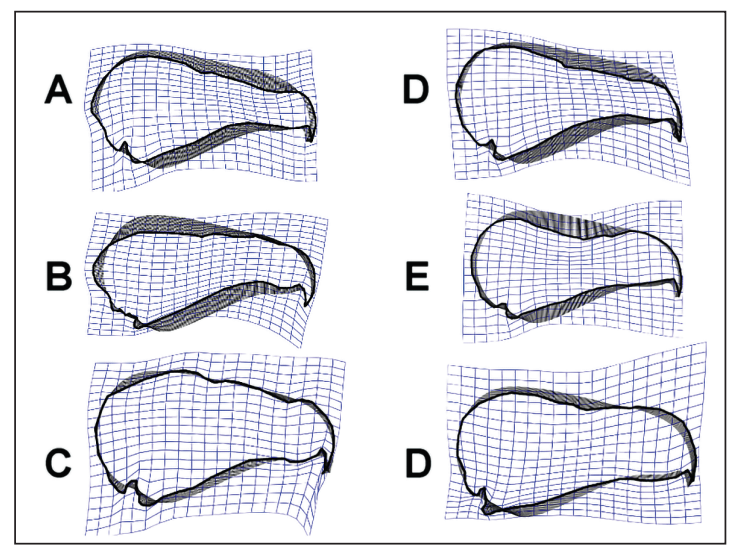

Figure 3. Various vulture species sharing very similar convergent attributes. A: Black Vulture (Coagyps atratus), B: Californian Condor (Gymnogyps caliornianus), C: King Vulture (Sarcoramphus papa), D: Hooded Vulture (Necrosyrtes monachus), E: White-backed Vulture (Gyps africanus), F: Rüppell's Griffon Vulture (Gyps rueppelli)

3. ábra Az egyes keselyűfajok hasonló konvergens bélyegeket hordoznak. A: Hollókeselyű (Coagyps atratus), B: Kaliforniai kondor (Gymnogyps caliornianus), C: Királykeselyű (Sarcoramphus papa), D: Csuklyás keselyű (Necrosyrtes monachus), E: Fehérhátú keselyű (Gyps africanus), F: Karvalykeselyű (Gyps rueppelli) 


\section{Results}

Our measures were significant, irrespective of measuring mode (all $r>0.97$, all $P<0.0001$ ). The first analysis focused on the whole skull from lateral view (Figure 2). We used sliding landmarks (800) to describe the cranial shape of the raptors. The first two PCs explained $59 \%$ and $17 \%$ of the variance in skull shape. The first PC axis described the relative height of the cranium (PC1). The Old World and New World vultures have long narrow head with relatively long beaks, while falcons and falconets have broad and round neurocraniums with short beaks. The second PC axis described the relative highness of the beak (PC2). Species like Lappet-faced Vulture (Torgos tracheliotos), Cinereous Vulture (Aegypius monachus), Philippine Eagle (Pithecophaga jefferyi) and Steller's Sea Eagle (Haliaeetus pelagicus) have high beaks and longer culmens. The Snail Kite (Rosthramus sociablis), Black Vulture (Coragyps atratus), Hooded Vulture (Necrosyrtes monachus) and Egyptian Vulture (Neophron percnopterus) have a very narrow and slender beak. Old World vulture and New World vulture species share similar morphology (Figure 3).

During the second analysis we used sliding landmarks (800) to describe the skull in dorsal view. The first two PCs explained $63 \%$ and $21 \%$ of the variance in shape (Figure 4 ). The first $\mathrm{PC}$ axis described variation in the relative size of the lacrimal bone and the beak (PC1). The

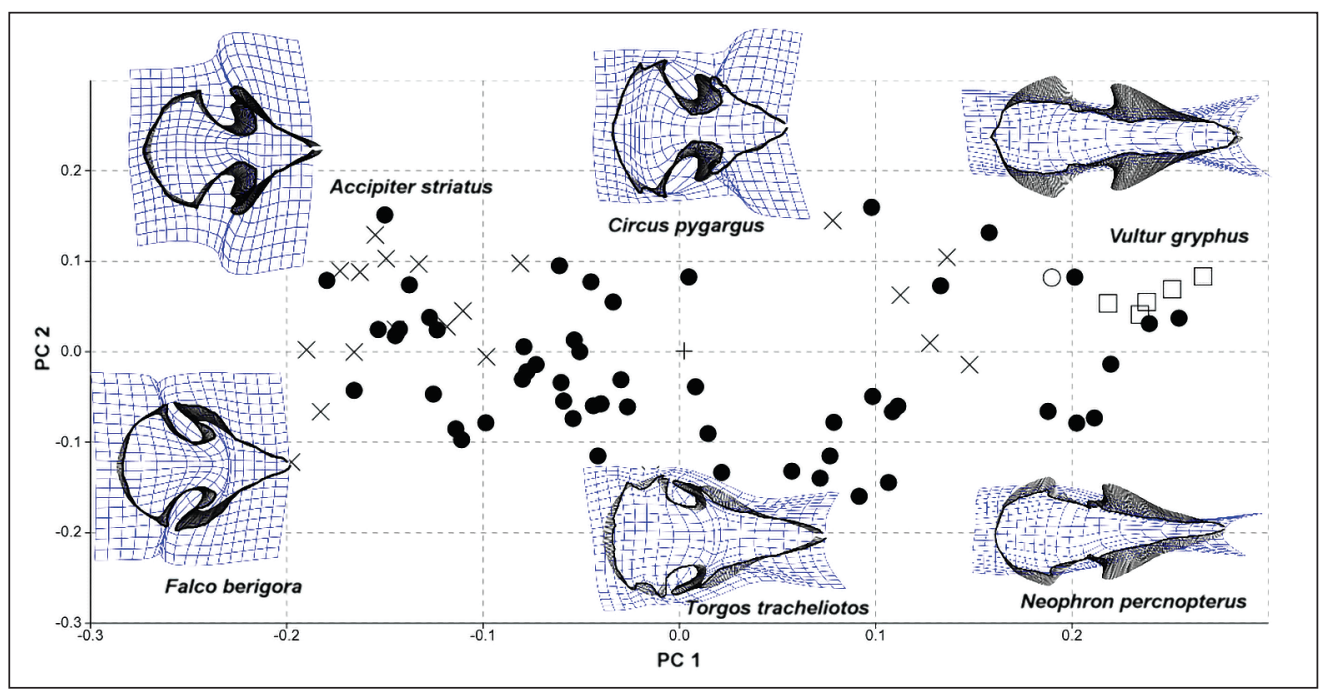

Figure 4. Graphical output of PCA performed on the two-dimensional landmark data (dorsal view). PC1-PC2 biplot. The first PC axis described variation in the relative size of the lacrimal bone and the beak (PC1). The second PC axis described differences in the orientation and robusticity of the lacrimal bone (PC2). Thick black areas show the differences compared to the computer generated mean shape

- Accipitridae, $\times$ Falconidae, $\square$ Cathartidae, $\bigcirc$ Pandionidae, + Sagittaridae

4.ábra A PCA grafikus megjelenítése kétdimenziós landmark adatok alapján (felülnézet). Az első főtengely (PC1) a könnycsont és a csőr relatív nagyságát, a második főtengely a könnycsont relatív helyzetét és robuszticitását magyarázza. A fekete, vastagított terület a komputergenerált átlagformától való eltérést mutatja

- Accipitridae, $\times$ Falconidae, $\square$ Cathartidae, $\bigcirc$ Pandionidae, + Sagittaridae 


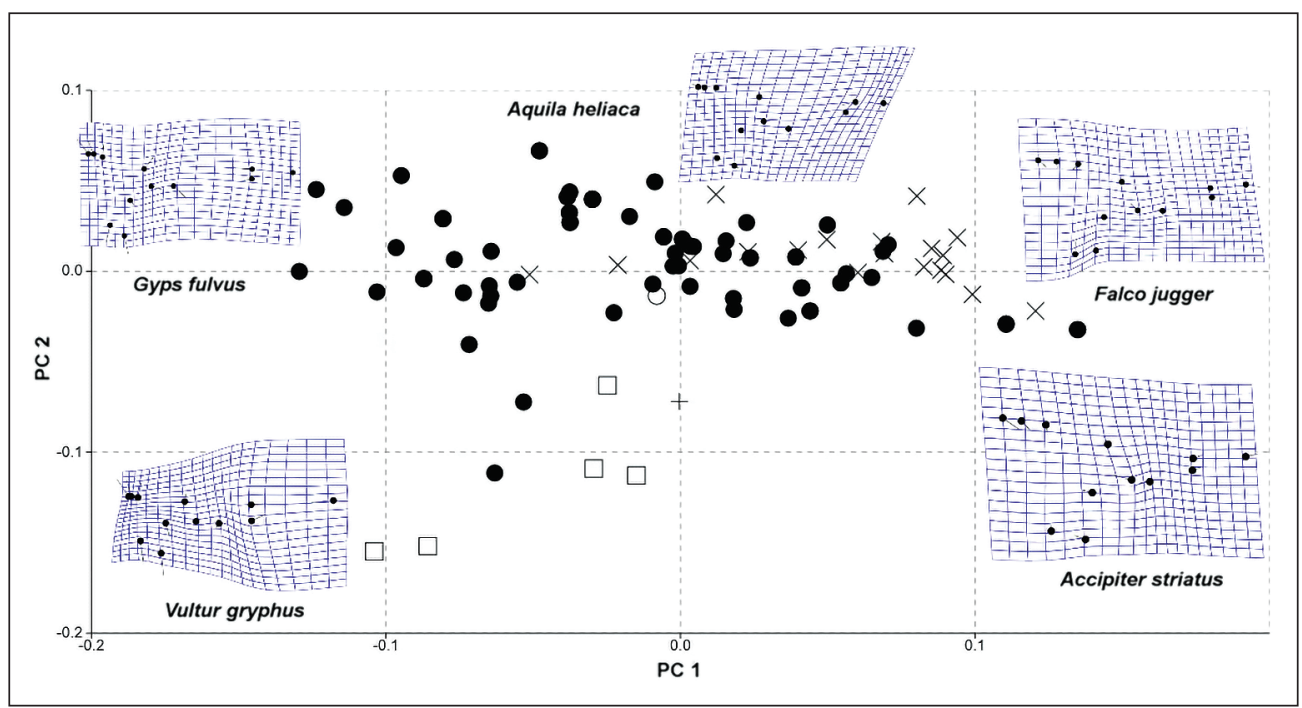

Figure 5. Graphical output of PCA performed on the two-dimensional landmark data (ventral view). PC1-PC2 biplot. The first PC axis described variation in the relative size of the neurocranium compare to the viscerocranium (PC1). The second reflects the relative size of the palatine bone and its distance from the tip of the beak (PC2). Thick black areas show the differences compared to the computer generated mean shape

- Accipitridae, $\times$ Falconidae, $\square$ Cathartidae, $O$ Pandionidae, + Sagittaridae

5. ábra A PCA grafikus megjelenítése kétdimenziós landmark adatok alapján (felülnézet). A PC tengelyek a neurocranium és a visceroscranium relatív nagyságát (PC1), valamint a palatinum relatív nagyságát és távolságát mutatják a csőrhegytől (PC2). A fekete, vastagított terület a komputergenerált átlagformától való eltérést mutatja

- Accipitridae, $\times$ Falconidae, $\square$ Cathartidae, $O$ Pandionidae, + Sagittaridae

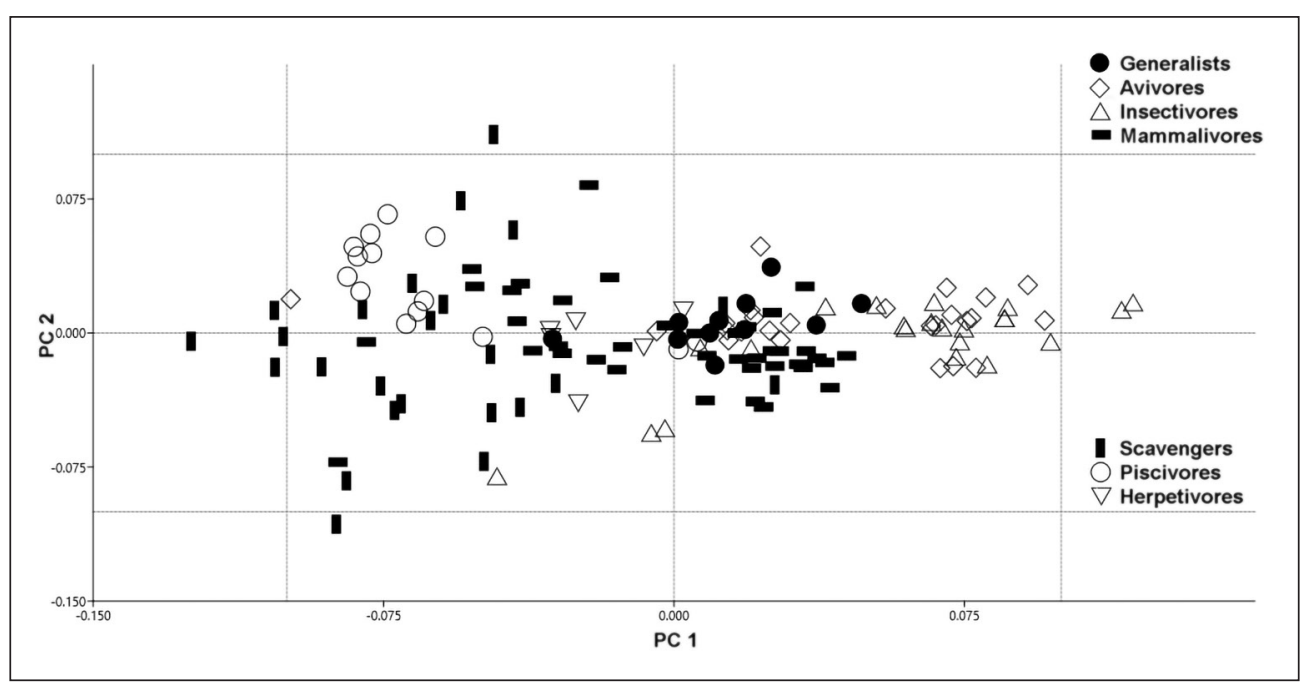

Figure 6. The species of different diet categories combined with the cranial shape in ventral view 6. ábra Kombinált ábra az egyes fajok oldalnézeti koponyaalakja és táplálékbázisa megjelenítésével 
falcons and Accipiter species have long lacrimal bones and shorter beaks compared with vultures with very tiny lacrimal bones and long beaks. The second PC axis (PC2) described differences in the orientation and robustness of the lacrimal bone (Figure 4).

The third analysis tried to describe the shape of the cranium fixed landmarks (12) in dorsal view. The first two PCs explained $52 \%$ and $21 \%$ of the variance in shape. The first PC axis described variation in the relative size of the neurocranium compare to the viscerocranium (PC1) and the second reflected to the relative size of the palatine bone and its distance from the tip of the beak (PC2). The analysis showed that New World vulture species differ considerably from other raptors (Figure 5).

In every case, the generalist species are in the middle of the morphospace.

We tried to identify the differences between the diet categories (Figure 6). There are no clear differences between the categories, as different groups are overlapping.

\section{Discussion}

We found that in the lateral view there are differences in the shape of the relative height of the cranium and the beak. Larger species have longer beaks compared to the neurocrani$u m$. The allometric head growth reflected variation in head length. It can explain some of the differences between species because the smaller species usually have bigger neurocranium and smaller viscerocranium. Allometric patterns within populations do not necessarily parallel interspecific allometry (Grant et al. 1985). The shape of the skull of vulture species (e.g. Andean Condor) strongly differs from the skull of small raptors like falconets (e.g Microhierax caerulescens) and small accipitrids (Accipiter nisus). But at the similar size, for example Egyptian Vulture (Neophron percnopterus) and bigger falcons (Falco cherrug, Falco rusticolus), species also strongly differ due to the variant foraging habits and mechanical demands. Smaller and slender beaks allow the bird to deftly collect small food items from difficult to reach places. The Snail Kite (Rosthramus sociablis), Black Vulture (Coragyps atratus), Hooded Vulture (Necrosyrtes monachus) and Egyptian Vulture (Neophron percnopterus) have very narrow and slender beak. Molluscivore Snail Kite extracts the food with a highly specialized bill from the snail shell (Bergmann et al. 2013). Smaller vulture species have similar bills due to the same conditions. These species are scavengers that feed primarily on carrions, collecting the small meat pieces from between the ribs, bones, and holes. This action demands a very similar beak shape. Larger vulture species have even larger and more hooked bills. Only the largest species (Lappet-faced Vulture and Cinereous Vulture) can tear open a big carcass, later allowing smaller vulture species to access the innards (Kruuk 1967, Schüz \& König 1983, Hille et al. 2016, Ballejo et al. 2018). Steller's Sea Eagle, Philippine Eagle and Harpy Eagle (Harpia harpyja) have also high beaks and long culmens similar to the larger vulture species. The diets of these predators' consist primarily of live prey. While tearing the prey, the bigger and stronger beak is necessary due to the larger size of their prey. Sometimes raptors swallow the prey animal whole but larger prey size demands that the raptor possess stronger beaks and requires them to use their feet and claws to tear apart their prey, enabling them to swallow the pieces bit by bit. 
Without big claws, larger scavengers need stronger adductor and neck muscles (Kulemeyer et al. 2009). In our analyses, the extinct Haast's Eagle (Harpagornis moorei) was morphologically closer related to vultures and sea eagles. The fossil data and remains suggest that the giant eagle was an active avivore hunter (Brathwaite 1992). Accipitrid raptor's feet and claws have a key role in immobilizing, killing and treating the prey (Csermely \& Gaibani 1998, Fowler et al. 2009). The skull morphology is reflecting more on foraging habits than diet or prey preference. The falcons have shorter and stronger beaks because these species are killing their prey with their bite (Hull 1991, Sustaita \& Hertel 2010). Like other bird taxa, the strong and tapered beak is in positive correlation with bite performance (Van der Meij \& Bout 2004, Herrel et al. 2005). As a result of convergent evolution, different scavengers share very similar morphology. These species have slender and lower skulls, longer bills, small sideward orbits, and caudally positioned quadrates. New World vultures can be distinguished by their large nostrils, narrow crania, and small orbits, and the nostrils are not divided by a septum.

The second analysis showed obvious differences between the Sharp-shinned Hawk (Accipiter striatus) and Andean Condor (Vultur gryphus). The orbit size is associated with the mobility and the size of prey. Scavengers have small orbits with very tiny lacrimal bones, due to dead and immobile prey. Orbits of other groups of raptors are even larger. The pursuit-hunter insectivores and avivores have very large orbits with long lacrimal bones which correspond with acute vision and broad visual field (Martin 2007). More evolved binocular vision enables them to examine environments without moving the neck (Jones et al. 2007). The orbits of these species are larger and more anterior in position (Heesy 2004). While flying, pursuit-hunters always catch prey by initiating quick, stooping attacks above prey animals (O'Rourke et al. 2010). The larger species also have large, round cranium which suggests that these species should have excellent flying and maneuvering skills.

Mammalivore species bear a reduced attachment area for the adductor muscles, a relatively large palatine, long maxilla, and caudally positioned quadrate (Sun et al. 2018). The caudally positioned quadrate can increase the bite force (Van der Meij \& Bout 2004). The herpetivore species have very similar attributes as mammalivore raptors due to the same mechanical demands. The mammalian and reptilian prey animals may have tougher skin (Hertel 1995).

The third analysis showed differences in the relative length of the cranium. Larger species have longer bills and more caudally positioned quadrate bone and foramen magnum occipitale. Aquila and Haliaeetus species have large palatine with wide quadrate bone. The other big raptors (Harpy and Philippine Eagle) share similar attributes. Convergent evolution and similar ecological demands allow that hawk and eagle-like species evolved in different subfamilies (Haring et al. 2007). We also found in our analyses that Caracara species are very close to buzzards and closer to the smaller vulture species in morphospace. These scavengers largely differ from the other falcon species. The New World vultures showed extremities with relative long and narrow craniums but relatively short and divided palatine bones with long maxilla. This could be due to the highly developed nasal region of these species; it is a well-known fact that these birds have excellent sense of smell whereas the Old World vultures find carcasses only by sight (Houston 1986). 
The study showed that the generalist species are in the middle of the morphospace, which corresponding with the relatively high degree of overlap in skull shape and diet. These non-specialised raptors are very successful and have a wide range in prey spectrum and distribution.

In future studies, it would be interesting to perform combined analyses with cranial shape and attributes of the leg and talons. Similarities in the skull shape can reflect also the phylogenetic relation. In this study, we did not investigate the effect of phylogeny. The phylogenetic control would be necessary in a further analysis.

\section{Acknowledgements}

We are grateful to Gábor Herczeg and János Török for their comments. We thank Péter Urtz, Ádám Pereszlényi, Tamás Glavanovics and Mihály Gasparik for the technical assistance. Special thanks to Emese Abaházi. The text was supervised by Erika Gál, Jenő Nagy, Veronica Johnson and Bridgette Dennett.

\section{References}

Adams, D. C., Rohlf, F. J. \& Slice, D. E. 2004. Geometric morphometrics: ten years of progress following the 'revolution'. - Italian Journal of Zoology 71(1): 5-16. DOI: 10.1080/11250000409356545

Anderson, R. A., McBrayer, L. D. \& Herrel, A. 2008. Bite force in vertebrates: opportunities and caveats for use of a nonpareil whole-animal performance measure. - Biological Journal of the Linnean Society 93(4): 709-720. DOI: 10.1111/j.1095-8312.2007.00905.x

Andersson, M. \& Norberg, R. A. 1981. Evolution of reversed sexual size dimorphism and role partitioning among predatory birds, with a size scaling of flight performance. - Biological Journal of the Linnean Society 15(2): 105-130. DOI: 10.1111/j.1095-8312.1981.tb00752.x

Andersson, M. 1994. Sexual Selection. - Princeton University Press, Princeton, NJ

Ballejo, F., Lambertucci, S. A., Trejo, A. \& De Santis, L. J. 2018. Trophic niche overlap among scavengers in Patagonia supports the condor-vulture competition hypothesis. - Bird Conservation International 28(3): 390-402. DOI: 10.1017/S0959270917000211

Bakaloudis, D. E., Vlachos, C. G. \& Holloway, G. J. 1998. Habitat use by Short-toed Eagles Circaetus gallicus and their reptilian prey during the breeding season in Dadia Forest (north-eastern Greece). - Journal of Applied Ecology 35(6): 821-828. DOI: 10.1111/j.1365-2664.1998.tb00001.x

Barker, F. K., Cibois, A., Schikler, P., Feinstein, J. \& Cracraft, J. 2004. Phylogeny and diversification of the largest avian radiation. - Proceedings of the National Academy of Sciences 101(30): 11040-11045. DOI: 10.1073/pnas.0401892101

Baumel, J. J. 1993. Handbook of avian anatomy: Nomina Anatomica Avium. - Publications of the Nuttall Ornithological Club (USA), no. 23.

Benkman, C. W. 2003. Divergent selection drives the adaptive radiation of Crossbills. - Evolution 57(5): 1176-1181. DOI: 10.1111/j.0014-3820.2003.tb00326.x

Bergmann, F., Amaral, H., Pinto, D., Chivittz, C. \& Tozetti, A. 2013. Foraging activity of the Snail Kite, Rostrhamus sociabilis (Aves: Accipitridae) in wetlands of southern Brazil. - Brazilian Journal of Biology 73(2): 245-252. DOI: 10.1590/s1519-69842013000200004

Bielefeldt, J., Rosenfield, R. N. \& Papp, J. M. 1992. Unfounded assumptions about diet of the Cooper's Hawk. - The Condor 94(2): 427-436. DOI: 10.2307/1369215

Bijleveld, M. 1974. Birds of prey in Europe. - Macmillan International Higher Education

Brathwaite, D. H. 1992. Notes on the weight, flying ability, habitat, and prey of Haast's Eagle (Harpagornis moorei). - Notornis 39(4): 239-247. 
Brown, C. J. \& Plug, I. 1990. Food choice and diet of the Bearded Vulture Gypaetus barbatus in southern Africa. - South African Journal of Zoology 25: 169-177. DOI: 10.1080/02541858.1990.11448207

Cade, T. J. \& Digby, R. D. 1982. The falcons of the world. - Harper Collins

Colwell, R. K. 2000. Rensch's rule crosses the line: convergent allometry of sexual size dimorphism in hummingbirds and flower mites. - American Naturalist 156: 495-510. DOI: 10.1086/303406

Cracraft, J., Barker, F. K., Braun, M. J., Harshman, J., Dyke, G. J., Feinstein, J., Stanley, S., Cibois, A., Schikler, P., Beresford, P., García-Moreno, J. Sorenson, M. D., Yuri, T. \& Mindell, D. P. 2004. Phylogenetic relationships among modern birds (Neornithes). - In: Cracraft, J., Donoghue, M. J. \& Donoghue, M. M. (eds.) Assembling the tree of life. - New York Oxford University Press, pp. 468-489.

Cramp, S. 1980. Handbook of the birds of Europe, the Middle East, and North Africa: the birds of the western Palearctic, Vol. 2. Hawks to bustards. - Oxford University Press

Csermely, D. \& Gaibani, G. 1998. Is foot squeezing pressure by two raptor species sufficient to subdue their prey? - Condor 100(4): 757-763. DOI: 10.2307/1369762

Csermely, D., Bertè, L. \& Camoni, R. 1998. Prey killing by Eurasian Kestrels: the role of the foot and the significance of bill and talons. - Journal of Avian Biology 29(1): 10-16. DOI: 10.2307/3677335

Csermely, D. \& Rossi, O. 2006. Bird claws and bird of prey talons: Where is the difference? - Italian Journal of Zoology 73(1): 43-53. DOI: 10.1080/11250000500502368

Dixon, A., Richards, C. \& King, A. 2018. Diet of Peregrine Falcons (Falco peregrinus) in relation to temporal and spatial variation in racing pigeon availability in Wales. - Ornis Hungarica 26(2): 188-200. DOI: 10.1515/orhu-2018-0028

Dumont, E. R. 2003. Bats and fruit: an ecomorphological approach. - In: Kunz, T. H. \& Fenton, M. B (eds.) Bat Ecology. - University of Chicago Press, Chicago, pp. 398-429.

Fabbri, M., Koch, N. M., Pritchard, A. C., Hanson, M., Hoffman, E., Bever, G. S., Balanoff, A. M., Morris, Z. S., Field, D. J., Camacho, J., Rowe, T. B., Norell, M. A., Smith, R. M., Abzhanov, A. \& Bhullar, B-A. S. 2017. The skull roof tracks the brain during the evolution and development of reptiles including birds. Nature Ecology \& Evolution 1(10): 1543-1550. DOI: 10.1038/s41559-017-0288-2

Fowler, D. W., Freedman, E. A. \& Scannella, J. B. 2009. Predatory functional morphology in raptors: interdigital variation in talon size is related to prey restraint and immobilisation technique. - PloS One 4(11): e7999. DOI: 10.1371/journal.pone.0007999

Gende, S. M., Wilson, M. F. \& Jacobsen, M. 1997. Reproductive success of Bald Eagles (Haliaeetus leucocephalus) and its association with habitat or landscape features and weather in southeast Alaska. - Canadian Journal of Zoology 75(10): 1595-1604. DOI: 10.1139/z97-786

Graham, I. M., Redpath, S. M. \& Thirgood, S. J. 1995. The diet and breeding density of Common Buzzards Buteo buteo in relation to indices of prey abundance. - Bird Study 42(2): 165-173. DOI: $10.1080 / 00063659509477162$

Graves, G. R. 2017. Sexual monomorphism in wing loading and wing aspect ratio in Black Vulture (Coragyps atratus) and Turkey Vulture (Cathartes aura). - Proceedings of the Biological Society of Washington 130(1): 240-249. DOI: 10.2988/17-00018

Grant, P. R., Abbott, I., Schluter, D., Curry, R. L. \& Abbott, L. K. 1985. Variation in the size and shape of Darwin's finches. - Biological Journal of the Linnean Society 25(1): 1-39. DOI: 10.1111/j.1095-8312.1985. tb00384.x

Guangdi, S. I., Dong, Y., Ma, Y. \& Zhang, Z. 2015. Shape similarities and differences in the skulls of scavenging raptors. - Zoological Science 32(2): 71-177. DOI: 10.2108/zs130253

Hackett, S. J., Kimball, R. T., Reddy, S., Bowie, R. C., Braun, E. L., Braun, M. J. \& Huddleston, C. J. 2008. A phylogenomic study of birds reveals their evolutionary history. - Science 320(5884): 1763-1768. DOI: 10.1126/science. 1157704

Hammer, Ø., Harper, D. A. T. \& Ryan, P. D. 2001. PAST: paleontological statistics software package for education and data analysis. - Palaeontologia Electronica 4: 1-9.

Haring, E., Kvaløy, K., Gjershaug, J. O., Røv, N. \& Gamauf, A. 2007. Convergent evolution and paraphyly of the hawk eagles of the genus Spizaetus (Aves, Accipitridae) - phylogenetic analyses based on mitochondrial markers. - Journal of Zoological Systematics and Evolutionary Research 45(4): 353-365. DOI: 10.1111/j.1439-0469.2007.00410.x

Helbig, A. J., Seibold, I., Bednarek, W., Gaucher, P., Ristow, D., Scharlau, W., Schmidl, D. \& Wink, M. 1994. Phylogenetic relationships among falcon species (genus Falco) according to DNA sequence variation 
of the cytochrome b gene. - In: Meyburg, B-U. \& Chancellor, R. D. (eds.) Raptor Conservation Today, WWGBP/The Pica Press, pp. 593-599.

Heesy, C. P. 2004. On the relationship between orbit orientation and binocular visual field overlap in mammals. - The Anatomical Record Part A: Discoveries in Molecular, Cellular, and Evolutionary Biology 281(1): 1104-1110. DOI: 10.1002/ar.a.20116

Herrel, A., Podos, J., Huber, S. K. \& Hendry, A. P. 2005. Bite performance and morphology in a population of Darwin's finches: implications for the evolution of beak shape. - Functional Ecology 19(1): 43-48. DOI: 10.1111/j.0269-8463.2005.00923.x

Hertel, F. 1995. Ecomorphological indicators of feeding behavior in recent and fossil raptors. - The Auk 112(4): 890-903. DOI: 10.2307/4089021

Hille, S. M., Korner-Nievergelt, F., Bleeker, M. \& Collar, N. J. 2016. Foraging behaviour at carcasses in an Asian vulture assemblage: towards a good restaurant guide. - Bird Conservation International 26(3): 263272. DOI: $10.1017 /$ S0959270915000349

Hinsley, S. A., Bellamy, P. E. \& Moss, D. 1995. Sparrowhawk Accipiter nisus prediction and feeding site selection by its. - Ibis 137(3): 418-422. DOI: 10.1111/j.1474-919X.1995.tb08042.x

Houston, D. C. 1986. Scavenging efficiency of Turkey Vultures in tropical forest. - The Condor 88(3): 318323. DOI: $10.2307 / 1368878$

Hull, C. 1991. A Comparison of the morphology of the feeding apparatus in the Peregrine Falcon, Falco peregrinus, and the Brown Falcon, Falco berigora (Falconiformes). - Australian Journal of Zoology 39(1): 67-76. DOI: 10.1071/ZO9910067

Itämies, J. \& Mikkola, H. 1972. The diet of Honey Buzzards Pernis apivorus in Finland. - Ornis Fennica 49: 7-10.

Jarvis, E. D., Mirarab, S., Aberer, A. J., Li, B., Houde, P., Li, C., Ho, S. Y. W., Faircloth, B. C., Nabholz, B., Howard, J. T., Suh, A., et al. \& Zhang, G. 2014. Whole-genome analyses resolve early branches in the tree of life of modern birds. - Science 346(6215): 1320-1331. DOI: 10.1126/science.1253451.

Jones, M. P., Pierce, K. E. \& Ward, D. 2007. Avian vision: a review of form and function with special consideration to birds of prey. - Journal of Exotic Pet Medicine 16(2): 69-87. DOI: 10.1053/j.jepm.2007.03.012

Korpimäki, E. 1985. Prey choice strategies of the Kestrel Falco tinnunculus in relation to available small mammals and other Finnish birds of prey. - Annales Zoologici Fennici 22(1): 91-104.

Kotymán, L., Solt, S., Horváth, É., Palatitz, P. \& Fehérvári, P. 2015. Demography, breeding success and effects of nest type in artificial colonies of Red-footed Falcons and allies. - Ornis Hungarica 23(1): 1-21. DOI: 10.1515/orhu-2015-0001

Kulemeyer, C., Asbahr, K., Gunz, P., Frahnert, F. \& Bairlein, F. 2009. Functional morphology and integration of corvid skulls-a 3D geometric morphometric approach. - Frontiers of Zoology 6: 2. DOI: 10.1186/17429994-6-2

Kruuk, H. 1967. Competition for food between vultures of East Africa. - Ardea 55(17): 1-193.

Ladyguin, A. 2000. The morphology of the bill apparatus in the Steller's Sea Eagle. - In: Ueta, M. \& McGrady, M. J. (eds.) First Symposium on Steller's and White-tailed Sea Eagles in East Asia. - Wild Bird Society of Japan, Tokyo, Japan, pp. 1-10.

Lindberg, P. \& Odsjö, T. 1983. Mercury levels in feathers of Peregrine Falcon Falco peregrinus compared with total mercury content in some of its prey species in Sweden. - Environmental Pollution Series B, Chemical and Physical 5(4): 297-318. DOI: 10.1016/0143-148X(83)90023-X

Martin, G. R. 2007. Visual fields and their functions in birds. - Journal of Ornithology 48(Suppl. 2.): S547S562. DOI: 10.1007/s10336-007-0213-6

Marugán-Lobón, J. \& Buscalioni, Á. D. 2006. Avian skull morphological evolution: exploring exo- and endocranial covariation with two-block partial least squares. - Zoology 109(3): 217-230. DOI: 10.1016/j.zool.2006.03.005

Massemin, S., Korpimäki, E. \& Wiehn, J. 2000. Reversed sexual size dimorphism in raptors: evaluation of the hypotheses in kestrels breeding in a temporally changing environment. - Oecologia 124(1): 26-32. DOI: $10.1007 / \mathrm{s} 004420050021$

McBrayer, L. D. 2004. The relationship between skull morphology, biting performance and foraging mode in Kalahari lacertid lizards. - Zoological Journal of the Linnean Society 140(3): 403-416. DOI: 10.1111/j.1096-3642.2003.00106.x

McCormack, J. E., Harvey, M. G., Faircloth, B. C., Crawford, N. G., Glenn, T. C. \& Brumfield, R. T. 2013. A phylogeny of birds based on over 1,500 loci collected by target enrichment and high-throughput sequencing. - PLoS One 8(1): e54848. DOI: 10.1371/journal.pone.0054848 
Mindell, D. P., Fuchs, J. \& Johnson, J. A. 2018. Phylogeny, taxonomy, and geographic diversity of diurnal raptors: Falconiformes, Accipitriformes, and Cathartiformes. - In: Sarasola, J. H., Grande, J. M. \& Negro, J. J. (eds.) Birds of Prey. Biology and conservation in the XXI. century, Springer, pp. 3-32.

Møller, A. P. \& Garamszegi, L. Z. 2012. Sexual selection, range size and population size. - Ornis Hungarica 20(1): 1-25. DOI: 10.2478/orhu-2013-0001

Moreno-Opo, R., Margalida, A., Arredondo, A., Guil, F., Martín, M., Higuero, R. \& Guzman, J. 2010. Factors influencing the presence of the Cinereous Vulture Aegypius monachus at carcasses: food preferences and implications for the management of supplementary feeding sites. - Wildlife Biology 16(1): 25-35. DOI: $10.2981 / 09-037$

Mueller, H. C. 1990. The evolution of reversed sexual dimorphism in size in monogamous species of birds. Biological Reviews 65: 553-585. DOI: 10.1111/j.1469-185X.1990.tb01238.x

Nagy, J. \& Tökölyi, J. 2014. Phylogeny, historical biogeography and the evolution of migration in accipitrid birds of prey (Aves: Accipitriformes). - Ornis Hungarica 22(1): 15-35. DOI: 10.2478/orhu-2014-0008

Newton, I. 1978. Feeding and development of Sparrowhawk Accipiter nisus nestlings. - Journal of Zoology 184(4): 65-487. DOI: 10.1111/j.1469-7998.1978.tb03302.x

O’Rourke, C. T., Hall, M. I., Pitlik, T. \& Fernández-Juricic, E. 2010. Hawk eyes I: diurnal raptors differ in visual fields and degree of eye movement. - PLoS One 5(9): e12802. DOI: 10.1371/journal.pone.0012802

Owens, I. P. F. \& Hartley, I. R. 1998. Sexual dimorphism in birds: why are there so many different forms of dimorphism? - Proceedings of the Royal Society B 265: 397-407. DOI: 10.1098/rspb.1998.0308

Pecsics, T., Laczi, M., Nagy, G. \& Csörgö, T. 2017. The cranial morphometrics of the wildfowl (Anatidae). Ornis Hungarica 25(1): 44-57. DOI: 10.1515/orhu-2017-0004

Pecsics, T., Laczi, M., Nagy, G., Kondor, T. \& Csörgő, T. 2018. Analysis of skull morphometric characters in Owls (Strigiformes). - Ornis Hungarica 26(1): 41-53. DOI: 10.1515/orhu-2018-0003

Pomichal, K., Vági, B. \& Csörgö, T. 2014. A case study on the phylogeny and conservation of Saker Falcon. - Ornis Hungarica 22(1): 1-14. DOI: 10.2478/orhu-2014-0007

Prum, R. O., Berv, J. S., Dornburg, A., Field, D. J., Townsend, J. P., Lemmon, E. M. \& Lemmon, A. R. 2015. A comprehensive phylogeny of birds (Aves) using targeted next-generation DNA sequencing. - Nature 526(7574): 569-573. DOI: 10.1038/nature15697

Puzović, S. 2008. Nest occupation and prey grabbing by Saker Falcon (Falco cherrug) on power lines in the province of Vojvodina (Serbia). - Archives of Biological Sciences 60(2): 271-277. DOI: 10.2298/ABS0802271P

Rohlf, F. J. 2010. TpsDig, version 2.16. - Department of Ecology and Evolution, State University of New York, Stony Brook, USA

Schüz, E. \& König, C. 1983. Old World vultures and man. - In: Wilbur, S. R. \& Jackson, J. A. (eds.) Vulture biology and management. - Berkley, Los Angeles: University of California Press, University of California Press, pp. 461-496.

Si, G., Dong, Y., Ma, Y. \& Zhang, Z. 2015. Shape similarities and differences on the skull of scavenging raptors. - Zoological Science 32(2): 171-177. DOI: 10.2108/zs130253

Sulkava, S., Tornberg, R. \& Koivusaari, J. 1997. Diet of the White-tailed Eagle Haliaeetus albicilla in Finland. - Ornis Fennica 74(2): 65-78.

Sun, Y., Si, G., Wang, X., Wang, K. \& Zhang, Z. 2018. Geometric morphometric analysis of skull shape in the Accipitridae. - Zoomorphology 137: 445-456. DOI: 10.1007/s00435-018-0406-y

Sustaita, D. \& Hertel, F. 2010. In vivo bite and grip forces, morphology and prey-killing behavior of North American accipiters (Accipitridae) and falcons (Falconidae). - Journal of Experimental Biology 213(15): 2617-2628. DOI: 10.1242/jeb.041731

Szövényi, G. 2015. Orthopteran insects as potential and preferred preys of the Red-footed Falcon (Falco vespertinus) in Hungary. - Ornis Hungarica 23(1): 48-57. DOI: 10.1515/orhu-2015-0004

Tóth, L. 2014. Numerical response of the Common Buzzard Buteo buteo to the changes in abundance of small mammals. - Ornis Hungarica 22(1): 48-56. DOI: 10.2478/orhu-2014-0010

Van der Meij, M. A. A. \& Bout, R. G. 2004. Scaling of jaw muscle size and maximal bite force in finches. Journal of Experimental Biology 207(16): 2745-2753. DOI: 10.1242/jeb.01091

Verwaijen, D., Van Damme, R. \& Herrel, A. 2002. Relationships between head size, bite force, prey handling efficiency. - Functional Ecology 16(6): 842-850. DOI: 10.1046/j.1365-2435.2002.00696.x

Ward, A. B., Weigl, P. D. \& Conroy, R. M. 2002. Functional morphology of raptor hindlimbs: implications for resource partitioning. - The Auk 119(4): 1052-1063. 
Yuri, T., Kimball, R. T., Harshman, J., Bowie, R. C., Braun, M. J., Chojnowski, J. L., Han, K-L., Hackett, S. J. Huddleston, Ch. J., Moore, W. S., Reddy, S., Sheldon, F. H., Steadman, D. W., Witt, Ch. C. \& Braun, E. L. 2013. Parsimony and model-based analyses of indels in avian nuclear genes reveal congruent and incongruent phylogenetic signals. - Biology 2(1): 419-444. DOI: 10.3390/biology2010419

Zelditch, M., Swiderski, D., Sheets, D. H. \& Fink, W. 2004. Geometric Morphometrics for Biologists: A primer. - Elsevier Academic Press, Waltham, MA.

Zusi, R. L. 1993. Patterns of diversity in the avian skull. - In: Hanken, J. \& Hall, B. K. The Skull, Vol. 2. Patterns of Structural and Systematic Diversity. - University of Chicago Press, pp. 391-437.

Zweers, G. A., Berkhoudt, H. \& Berge, J. V. 1994. Behavioral mechanisms of avian feeding. - In: Bels, V. L., Chardon, M. \& Vandewalle, P. 1994. Biomechanics of feeding in vertebrates. - Springer, Berlin, Heidelberg, pp. 241-279.

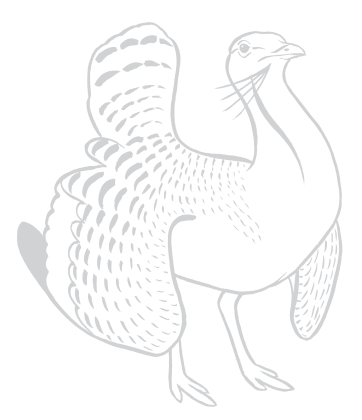

